\title{
The university teacher: Catalyst of the emotional-technological-ontological logic in the teaching of exact sciences
}

\section{El profesor universitario: Catalizador de la lógica emocional-tecnológica-ontológica en la enseñanza de las ciencias exactas}

DOI: $10.46932 /$ sfjdv2n5-102

Received in: Oct 1st, 2021

Accepted in: Dec 30th, 2021

\author{
Mendoza Velazco Derling Jose \\ Camara Minera del Peru CAMIPER Lima Peru \\ E-mail: dmendoza@grupocamiper.org
}

Cejas Martinez Magda Francisca

Universidad Nacional del Chimborazo UNACH, Universidad de las Fuerzas Armadas ESPE, Ecuador

E-mail: magdacejas09@gmail.com

\section{Villavicencio Álvarez Víctor}

Universidad de las Fuerzas Armadas ESPE, Quito, Ecuador,

E-mail: vevillavicencio@espe.edu.ec

Flores Hinoztroza Elizeth Mayrene

Universidad Nacional de Educación UNAE Chuquipata, El Cañar, Ecuador

E-mail: elizethfloress2005@gmail.com

Navarro Cejas Mercedes

Universidad Tecnica de Manabi UTE, Manabi, Ecuador

E-mail: mercedes.navarro@utm.edu.ec

\begin{abstract}
The aim of the study was to design a theoretical approach to the existing techno-ontological logical emotions of university mathematics teachers working in universities in Ecuador. The research was qualitative. For the selection of the sample, a random selection was carried out under the criterion of intentionality. Twenty (20) students and eight (8) mathematics teachers from different universities participated. For data collection, we used a participatory digital observation guide and an open-ended interview. Three categories emerged from the results: the andragogic retrotopia of being a mathematician, the emotional scar in teacher training and the educational perception of the university student. We conclude with a theoretical approach in which the deficit of professional digital training in mathematical sciences allows the emotional logic of the Ecuadorian teacher to drive him/her to portray an academic being that generates hatred and rejection in the university educational community.
\end{abstract}

Keywords: Mathematics, technology, University Education, Emotions, virtual education.

\section{RESUMEN}

El objetivo del estudio fue diseñar una aproximación teórica a las emociones lógicas tecno-ontológicas existentes en los profesores universitarios de matemáticas que trabajan en las universidades del Ecuador. La investigación fue cualitativa. Para la selección de la muestra se realizó una selección aleatoria bajo el criterio de intencionalidad. Participaron veinte (20) estudiantes y ocho (8) profesores de matemáticas de 
diferentes universidades. Para la recolección de datos se utilizó una guía de observación digital participativa y una entrevista abierta. De los resultados surgieron tres categorías: la retrotopía andragógica de ser matemático, la cicatriz emocional en la formación docente y la percepción educativa del estudiante universitario. Concluimos con un planteamiento teórico en el que el déficit de formación profesional digital en ciencias matemáticas permite que la lógica emocional del profesor ecuatoriano le lleve a retratar un ser académico que genera odio y rechazo en la comunidad educativa universitaria.

Palabras clave: Matemáticas, tecnología, Educación Universitaria, Emociones, educación virtual.

\section{INTRODUCTION}

The Covid-19 pandemic is currently being experienced worldwide, forcing a definitive change in academic activities from face-to-face to virtual mode. Universities are developing socialization processes among the members of the educational and scientific community. These processes seek the best alternatives for the training of their actors at a technological and virtual level. In this sense, training is framed within the framework of aspects that allow for its adequate development. For this reason, various processes are assumed, technological and mathematical education, which is presented according to the evolutionary stages of being. University education administered in both public and private universities. They offer society all the courses in the university curriculum, English, physics, chemistry, biology, geography, history, among others.

This situation progressively favours the inter-disciplinary and trans-disciplinary approach of the university system. The insertion of professionals contributes to the andragogical spaces of knowledge that promote professional development. They also raise the development of situations where the professionalism of the university teacher is promoted.

The university teacher must have full mastery of didactics, andragogy and pedagogy. The complexity of the above is assumed from an integral perspective, given the need to study the practices of university teachers. These perspectives are within the framework of mathematics, emotions and technology. To this end, research is carried out based on the rigorousness of the scientific method. Assuming the study of the techno/ontological emotional logic of university mathematics teachers in Ecuador.

\section{THEORETICAL SUSTAINING}

\subsection{THE CURRENT ANDRAGOGIC RETROTOPIA OF THE MATHEMATICAL BEING}

Mathematics is a universal science that is very useful and has many benefits in the learning of other disciplines. Mathematics fosters the development of science and technology; it plays a role in the advancement of human thought. Mathematics can reveal hidden patterns that can help humanity 
understand the phenomena around them (Fatima, 2012). In the activities of life, humans will never be separated from mathematics. Many human activities are carried out using mathematical concepts. Likewise, many problems are tackled using mathematical models as a method to solve them (Arévalo et al., 2021).

Melgarejo (2015) points out that we conceive of mathematics education as a discipline. It is a set of organised knowledge, the object of study of which is the relationship between knowledge and its teaching. For mathematics teaching to be generated, there must be knowledge, so that both elements constitute a phenomenon that serves as a guide. There must also be a critical approach to the teaching of mathematics. The teaching of numeracy is also known as mathematization, according to Treffer (2008). The cited author states that mathematizing is organizing and structuring the information that appears in a problem. It is identifying the relevant mathematical aspects, discovering regularities, relationships and structures.

Retrotopia according to Bauman (2017), exalts a conscious and incisive yearbook on nostalgia for a past considered better in comparison to the current situation. In relation to mathematics, mathematical retrotopia is consolidated with beliefs to the educational environment. The main goal of learning mathematics is to develop problem-solving skills. Based on mathematical retrotopia, the past as an applied method is questioned. Retrotopia applies a comparison between the traditional method (face-to-face education) and the current method (virtual education on educational platforms).

To perceive this definition and its occurrence within mathematical instruction, it is necessary to understand the past. It is necessary to verify whether the didactic techniques and strategies of face-to-face teaching were effective or not. To verify effectiveness, they must be applied in an impartial research environment to obtain accurate data on the construction of meaningful learning (Ortiz et al., 2021).

\subsection{THE EMOTIONAL SCAR IN TEACHER TRAINING}

Teacher training is one of the most important elements in the development of education. It aims to strengthen the teaching and learning process. Pizarro (2013) argues that teaching is a profession whose specificity focuses on teaching. In this case, the training of the teaching professional lies in providing the subject with a series of knowledge. Knowledge that serves as a basis for teaching at the level at which he or she is professionally placed. It is also necessary to be committed, given that their actions are intentional. To achieve training, the subject "prepares to train", and this is where the true essence of this committed work lies.

Universities live a very different reality with the Covid-19 pandemic. Many teachers are preoccupied with fulfilling a programmed of digital content and most of the time leave aside the motivational interests of their students (Mendoza, et al., 2021). Díaz (2002) points out that "very few teachers explore students' opinions or suggestions". He also mentions that "we do not provide space for 
them to put forward their own options for educational work". Only in this way can we see if we are failing in something indispensable in education. The teacher becomes only a transmitter of knowledge. The concern goes on until the moment the student passes the evaluation of the subject. After passing, the knowledge necessary for daily life is left aside. Teachers in general have lost their commitment to the development of an adequate training process. They jeopardies the development of the university student's thinking, including emotionality. In this case, it must be argued that teachers have given more importance to the conceptual part than to procedures. Procedures are required for the achievement of adequate teaching. It must be argued that the development of the human being is a function of thinking and this is not being considered (Yerizon et al. 2018).

The teacher must pay attention in a specific way to the situations specific to the content. Sometimes they ignore treating the student as a subject with emotions, thus compromising the development of emotional intelligence in the students. Teachers do not adopt strategies that contribute to this end. Salmeron (2000) points out that schools are taking it upon themselves to curtail the emotions of the very young. The teaching is as strong as steel, i.e. they are not allowed to have feelings. In today's virtual classrooms, computers are more important than people. Expressions of affection, affection and in many cases even pain are left aside.

According to Mohd et al. (2016), it is necessary to indicate that universities hardly promote the development of technological emotions. They only develop excessive content, where there is no time for the expression of emotions. In this way, students are held back from developing emotional intelligence. This leads to the rejection of actions where expressions find a place. For example, there is evidence of university contexts lacking in emotions and humanism, where individualism prevails. All this to the point that the development of appropriate actions is left behind. Actions for the construction of phenomena inherent to the development of the subject's thinking.

The above situation is present in ten (10) Ecuadorian universities during the 2020-2021 academic year. It was possible to appreciate that due to the pressure of complying with the virtual programmed, teachers put aside creativity, didactics and motivation in their classes. This turns them into professionals with routine, obsolete and/or traditional methods. Although there is a high level of commitment and dedication to ensuring that students obtain good marks in the different academic tests. It is also evident that teachers are leaving aside the involvement of emotions. Emotions are considered a necessary competence for the explanation and development of mathematics according to Mendoza et al. (2018) and Amalu (2018).

In the light of the above, emotional intelligence is the way we act in certain moments. Whether it is expressions of anger or joy, the way human beings react to any situation is very different. These situations play a fundamental role in the management of emotions. According to Garcia (2011), "the most 
significant attribute of interpersonal intelligence is the ability to understand and interact with others" (p. 7). These attributes indicate that interpersonal communication is intelligently concerned. It is also possible to distinguish the emotions, temperaments, motives and intentions of others (Goleman, 1996).

\subsection{THE EDUCATIONAL PERCEPTION OF THE COLLEGE STUDENT}

The educational process and academic production are linked to the concept of university competences (Iranzo et al., 2018). Educational development and empowerment are what is sought in the course of everyday university life. Not only as a procedural dynamic of knowledge construction, but also in relation to know-how. The aim is to make progress in skills, abilities, attitudes, intrapersonal and interpersonal relationships and with the environment in which the student develops (Mendoza et al., 2019).

According to Katartzi \& Hayward (2020), nowadays in times of Covid-19 pandemic and virtual education, students need to be technologically prepared. Students' personal approaches and visions originate from the moment they start university. The customs or beliefs of virtual education are not like face-to-face education according to the student body (Bottia, et al., 2020). University education has always tried to do its best, but inevitably students must join courses where they must reinforce and really learn the contents. Sometimes students only study to pass tests (Bottia, et al., 2020). For Young, et al., (2020) fortunately students pay special and due attention to their participation in and organization of university education only at the end of their studies.

Recent studies show that less than $30 \%$ of students have a good sense of direction in higher education. But $70 \%$ have poor decision-making or career choice skills. Today's student body perceives their university education with a particular focus on their view of learning, responsibility, commitment and satisfaction. These approaches are taken up by students through responsibility, education and learning (Guo, Hong \& Coates, 2020).

Lack of research in high school is a negative trigger for students at university. Students perceive higher education as a big turnaround or change in preparation. Similarly, students rely on the opinions of other peers. They do not compare opinions from various sources or levels about university educational processes. Therefore, students do not really value their virtual education. Many find it unemotional and boring and it decreases performance. For others, it is becoming more popular to rush through virtual education to obtain a degree without appreciation or affection for the course. There is also research indicating that students believe that having an education is a guarantee of a good job in the future. But this vision or belief generates changes or ruptures when living a reality different from the one promised by the university (Krishnapratap, Dasgupta \& Vispute, 2020).

According to Spindel (2020), students must show respect for themselves and their own development. The understanding of how students perceive their virtual mathematics activities should be 
clarified as early as possible. Students can begin to understand the value of their own contribution and investment in education, then value their experience. Motivating interest in learning mathematics is therefore an unavoidable and indispensable task. It is necessary to innovate in virtual classrooms, especially as teachers must keep pace with the world. It is not possible to continue educating a generation using practices that are out of technological context, obsolete and competitively backward. Students and the world today are immersed in environments in which they are harassed. Harassed by inordinate flows of information, which allows them to have negative academic knowledge of educational sciences.

\subsection{OBJECTIVE OF THE RESEARCH}

To develop a theoretical approach to the existing techno-ontological emotional logic of university mathematics teachers working in Ecuadorian higher education institutions.

\section{METHOD}

The research was designed under a qualitative approach. Study of the phenomenological paradigm. This paradigm seeks to know the meanings that individuals give to their experience, through the process of interpretation. Through the qualitative design, mathematics teachers and students define their environment and act accordingly (Guerrero et al., 2017). Based on the qualitative scheme, 10 universities that develop pedagogical components were selected. The non-statistical purposive sampling technique was applied. This method facilitated the selection through arguments of the population. Otzen and Manterola, (2017) recommend using this technique in research settings where the sample and population are diverse and small. The researchers sent digital letters via email for virtual research participation. For reasons of prevention and Covid-19 health logistics, no face-to-face activities or crowding were allowed. Twenty (20) students from different careers participated. Students who are between 6 and 10 semesters. They are considered capable and committed students. Eight (8) mathematics teachers were chosen, graduates from different national and international universities. Both sets were considered as key informants (students and teachers).

\section{RESEARCH INSTRUMENTS}

Two instruments were used for data collection. The first instrument was the non-participatory digital observation guide (see Table 1). The researchers accessed the virtual mathematics activities with the mutual agreement of the teachers and students. Observation allowed the researchers to obtain information about the phenomena or events as they occur in the environment (Rekalde et al., 2014). 
Table 1. Digital observation guide applied by researchers in math activities.

\begin{tabular}{ll}
\hline Research by the university math teacher & $\begin{array}{l}\text { Observation guide } \\
\text { Observations }\end{array}$ \\
\end{tabular}

Time for Math activities:

Duties, tasks and digital tools attached:

Type of platform or virtual system of activities:

Organization and structure of classes:

Student-teacher relationship

Behaviors:

Emotions:

Affections:

As a second instrument, the semi-structured web interview via Google Meet was applied. Individually, the interview was applied to obtain specific information on teachers' and students' vision and understanding of university mathematical training. Questions were opened (see Table 2).

Table 2. Questions asked in the interview with teachers and students.

Research by the university math teacher

Informant:

Questions:

How you define a math teacher?

Numerical sciences are easy or complex?

How you rate virtual math activities?

In the process of teaching and learning mathematics you strategy

or teaching resource recommend applying? 


\section{DATA ANALYSIS PROCEDURE}

The interview data were transcribed using the current version of Dragon Naturally Speaking software. The transcripts were then coded and the testimonies were placed as D.1. D.1 represents the accounts expressed by the first teacher. Similarly, D.2 represents the second teacher's account. Based on the students' testimonies, code E.1 was used. E.1 represents the dialogues expressed by the first student. In succession (E.2) the second student. For the analysis of the data, the theoretical triangulation method recommended by Gaitán and Lozano (2012) was used. These methods allow the formulation of theories or theoretical approaches that emerge from the contrast of qualitative data (interview, observation, theories, studies of critical authors and contributions of the researchers). For the digital contrastation of data, the qualitative analysis operating system ATLAS.ti version 8 was used. The software produced the emerging categories that provided the theoretical formulation of the research (Mendoza et al., 2020).

\section{RESULTS}

After triangulating the theoretical underpinnings of the research with the data collected from the interview and observation guide, the following categories emerge:

Figure 1. Category 1, the andragic retrotopia of the mathematical being.

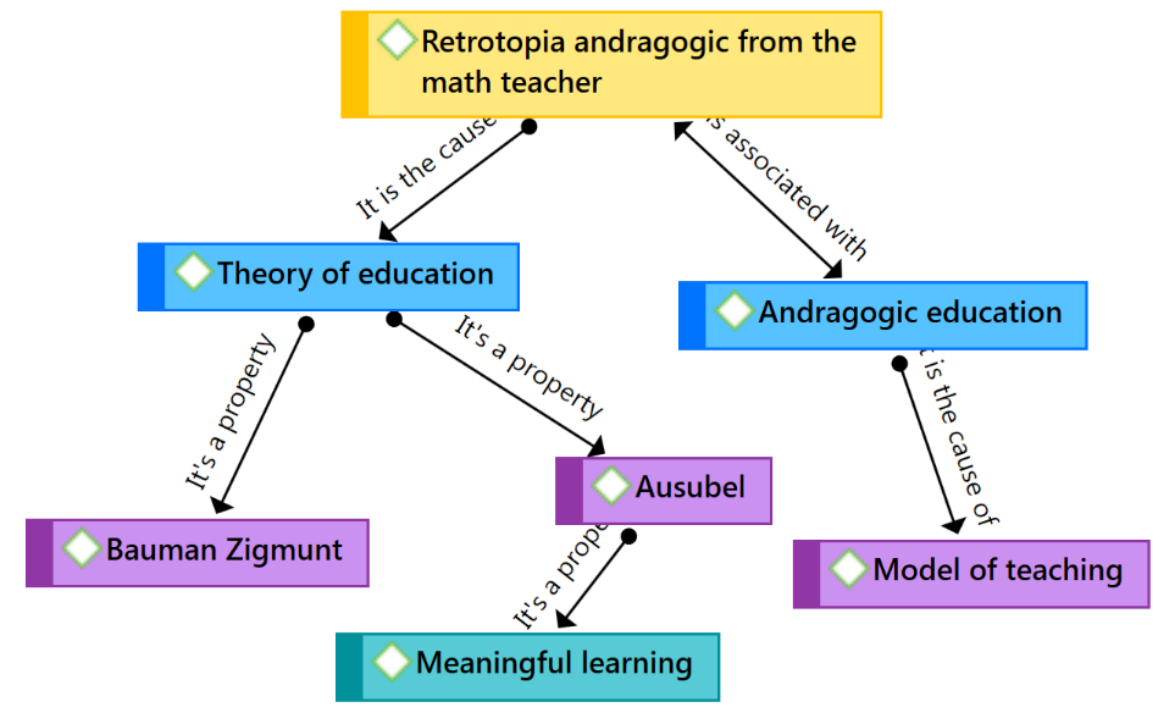

Among the data provided by student E.2, he indicates that "mathematics teachers always emphasize a nostalgic past". Similarly, E.5 says, "mathematics education had better results in previous years". In this way, a frequent cycle is created, which is transmitted by the students. Indicating that in the past they taught and learned in a better way, as opposed to nowadays. According to what has been expressed, when studying virtually everything is easier, quicker and simpler to solve. Mathematical 
problems can be solved because they are already on the web. For E.18 "it is difficult to understand the classes, since everyone in the virtual classroom must coordinate the questions or doubts", synchronization is described as a discomfort in the virtual modality of the students. As for the face-to-face mode, for E. 20 "two years ago when we were in the classroom, we could ask questions and it seemed more comfortable and practical to do exercises" (Figure 1).

Teachers D.2 and D.8 in their interviews made a comparative emphasis on the use of "calculators or mathematical operating systems such as Wiris and GeoGebra that solve everything". Informant D.3 emphasized that "many teachers are uncomfortable or annoyed to see a student solving with the help of digital systems, that is an obstacle to meaningful learning". On the contrary, according to E.15 "teachers must accept that we use digital resources to solve calculation tasks, so nothing makes sense in virtual education". Based on the observations in the participatory activities. It was possible to perceive an educational system where the teacher highlights the difficulty of the virtual teaching and learning process. They also state that it is difficult to guide students without being face to face. After contrasting the testimonies, the observations and the theoretical underpinnings of the research, the Atlas.ti software produced the first category (see Figure 1). Category 1 of an emergent type called andragogic retrotopia of the university mathematics teacher. The retrotopia as a theoretical basis of the author Bauman, (2017) where the relationship of sociology with meaningful learning and the theoretical contributions of Ausubel (1976) is manifested. In this way the student perceives the image of the mathematics teacher. In a symbolic interactive way with technology or online education, the student detects the image of an academicist or rigid education.

Figure 2. Category 2, the emotional scar in teacher training

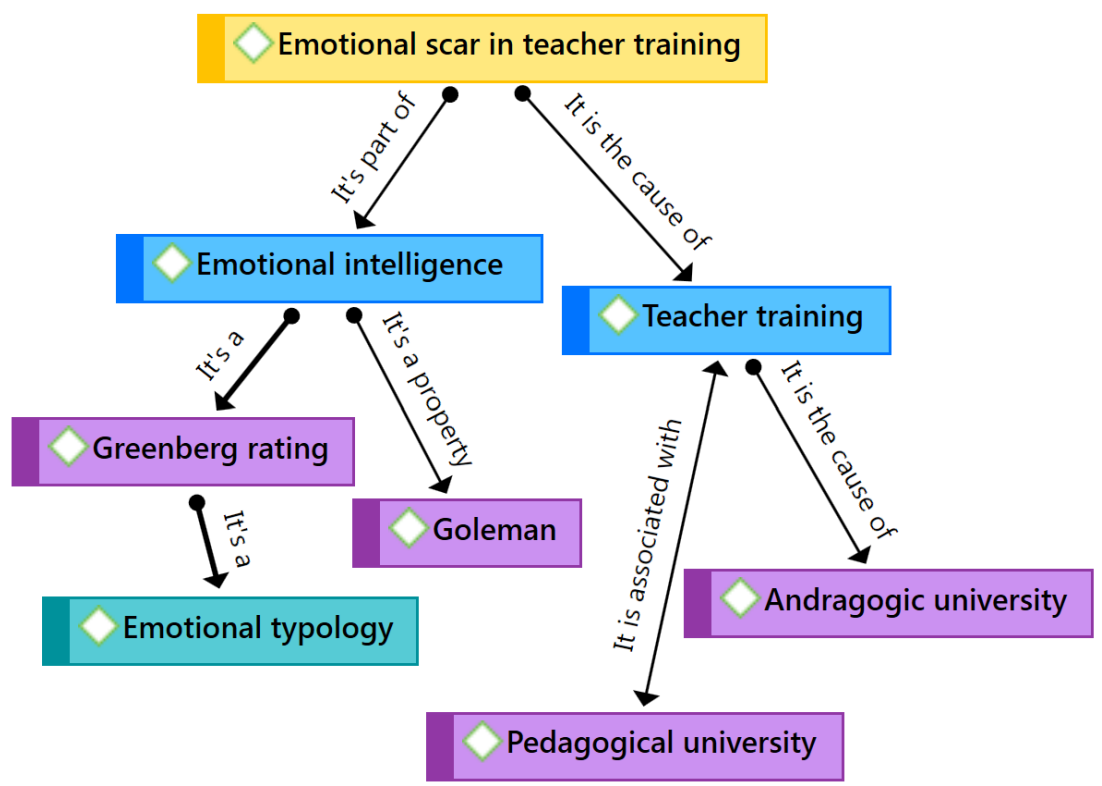


The emotional scar in teacher education emerges as the second category (see figure 2). This category is supported by Young and Suri's theory (2020) that there are six basic emotions (fear, anger, sadness, disgust, surprise and joy). Emotions are classified into primary healthy, primary unhealthy, reactive and instrumental emotions (Young and Suri, 2020). A second theory is that described by Goleman (1996), of emotional intelligence. Defined as the ability to recognise one's own feelings and those of others. Based on the observations and testimonies described, E.18 emphasized that "teachers have a thirst for revenge against us", and E.11 stated that "many mathematics teachers make me react with sadness, anger and fear".

As for class time for E.6 "we have our worst opponent, time". For E.9 "whenever I have a math's homework or homework, I suffer a lot". Also E.1 "when the teacher assigns us homework, he only gives us 50 minutes. He doesn't understand that we have to solve 20 exercises. The worst thing is that he doesn't measure the time, that we have to take pictures, scan the exercises, and then upload them to the Teams system. They don't understand that there can be failures on the internet. What can I do if my computer is not working properly? E.11 says that when it comes to virtual assessments, "I always suffer from anxiety. I don't know if I have enough time". Similarly, E.2 "one day I had a power failure, I handed in the evaluation minutes late. My grade was two points lower".

Regarding problem solving methods, E.3 says "I try to do the exercises with factoring. This way, I will have time to correct and check. But the teacher graded me badly, he wants me to solve only as he says". According to the testimonies, students suffer severely with the activities due to lack of consideration in time and evaluation. Teachers may disqualify them or lower their marks because of time limits. There is no consideration for the setbacks that crowd the activities. These anxieties generate emotions of anger, despair and hatred for the teacher, as well as for mathematics. Student E.7 expresses that "fear has been instilled by teachers". Fears are formed by seeing the teacher as a being who seeks supremacy in the university society. E.9 states, "teachers think they are the most powerful when they have the largest number of deferred students".

On the other hand, teacher D.1 says "students always lie in the evaluations. The internet is always broken, the electricity is always broken, the cameras are always damaged. They do it with the intention of copying the results". D.3 says, "our professional educational training was pedagogical but not andragogical". The teachers state that there is never any connection problem, they are only techniques to copy the results. They also say that they received an academic training of students at the basic and diversified level. These teachers were not trained for the university andragogical level. Also, for D.5 there is "lack of continuous training in teacher professionalization". The contracted mathematics teachers have degrees in administration, engineering, accounting, economics or other branches. Especially for D.7 and D.2, they stated that, having received a "rigid and academicist training, they will provide an equal 
education to their students". In this way, according to the students' testimonies, a cyclical emotional scar is generated. For reasons of time in the virtual assessment, technological materials, lack of communication and trust. Also due to lack of communication and trust. Lack of professional university training. These emotions of fear and anger are transmitted to the students.

Figure 3. Category 3, the educational perception of the university student

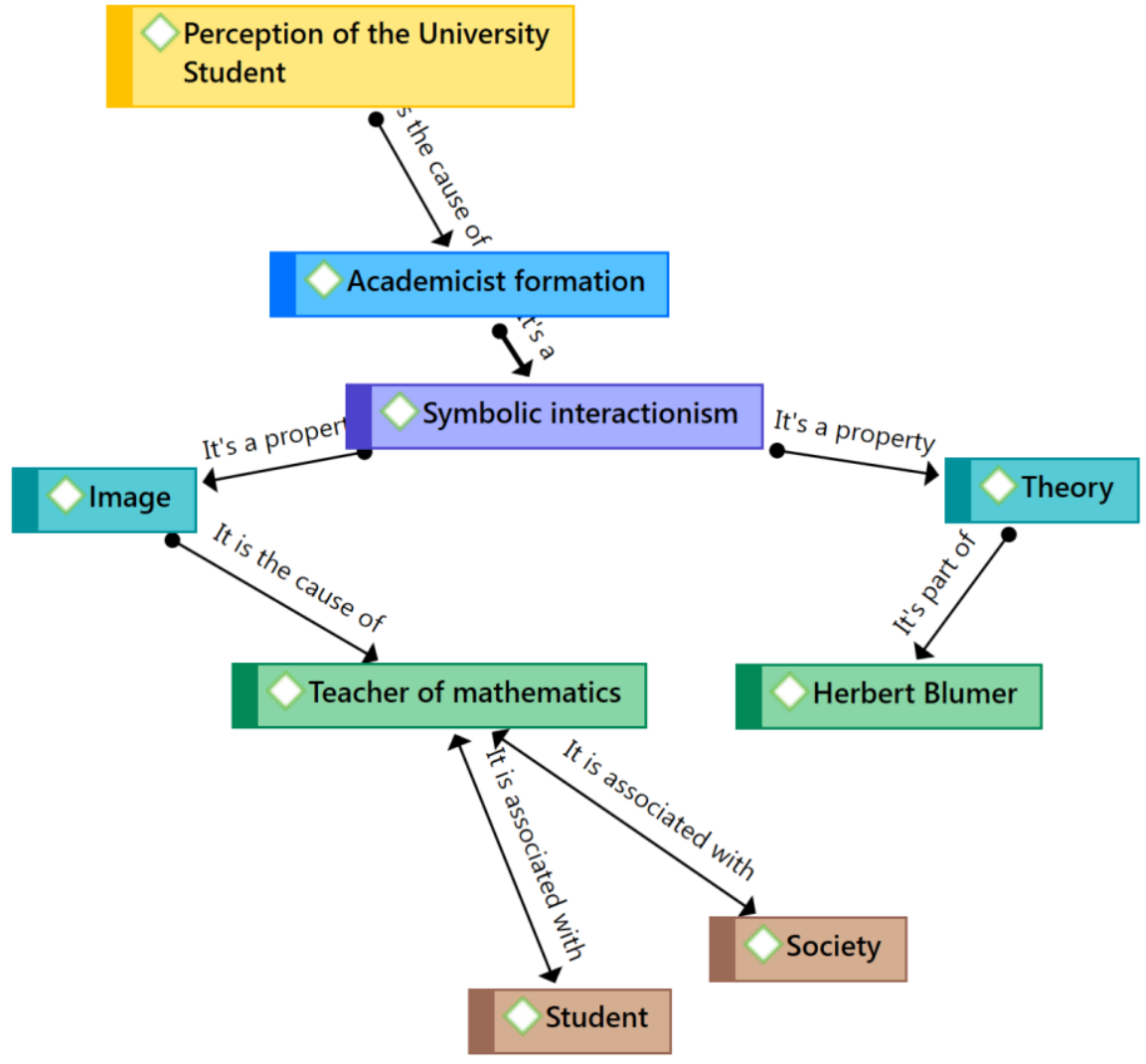

Figure 3 shows the third category catalogued as the educational perception of the university student. Through the observations perceived by the researchers, the Ecuadorian student has always been framed by behaviourist or academicist teaching. Informant E.13 says, "my teacher always tells me, solve the exercise as I teach you, as I have asked you to, don't do other things that I haven't asked for". Blumer (1969), in his theory of symbolic interactionism, emphasises that the ability to think is shaped by social interaction. Therefore, if a teacher demands a single model of problem solving, he demonstrates a behaviourist model (academicist model).

E.19 points out, "I perceive the teacher as a very fearful man". Informant E.20 defines the university mathematics teacher as "a very hard person, who does not allow mistakes in the exercises". In this way, the students visualise the mathematics teacher as being very rigorous and fearful. This image of a rigid teacher is common in Ecuadorian society. According to E.1 "when I was a child, I remember my 
parents saying that teachers were always right. Now that I am at university, I see everything differently". For the researchers, the Ecuadorian family sees the mathematics teacher as an elite being. They are perceived in this way, as they possess knowledge of the exact sciences. The perception of virtual mathematics activities is not pleasant at the evaluative level. According to E.3 "it is not the same to be assessed by a machine as to be assessed by the teacher. Before, the teacher checked me and sometimes he could consider my results. But virtually, if any value is wrong, the whole result is negative.

This way, I get a bad result". Regarding recommended resources or strategies, E.17 mentions "we need digital didactic activities. We need the teacher to interact in a practical and digital way with us". For E.18 "the teacher sets up the camera and uses the acrylic board. It is the same technique as in face-to-face classes". The testimonies demonstrate the need for digital didactics in mathematics classes. On the other hand, according to D.6 "we have to keep control of the classes, otherwise these kids would make a mess". Teachers emphasize that they must maintain affective control through constant fear in the student population. The teacher gives off an image of never making a mistake. The teacher always longs to be perceived as a perfect entity for the logical reason of calculation.

\section{CONCLUSION}

After contrasting the testimonies - theories of teachers and students. The university mathematics teacher is a catalyst axis. This axis is composed of emotional, technological and ontological logic in the teaching of mathematics. The teachers expressed that virtual education is a process that they have mastered, but it requires improvement. The leading role of the university teacher as a catalyst associated with technology is the most transformative factor in determining its integration. The virtual education technique requires digital didactic changes. Students have an optimistic side in learning. But the evaluative quality generates a pessimistic view. A negativism towards virtual activities was revealed during the Covid-19 pandemic. This type of negativism is also known as technophobic according to Gadanidis, Clements and Yiu, (2018).

Teacher education should be linked to digital updating. In general, the research conforms to this dichotomy, although educators play the most important role in university training. The student is more closely linked to the face-to-face classroom teacher as opposed to the virtual classroom. In the light of the above, the development of human beings is framed in the constitution of different aspects. It is necessary to highlight the importance of emotions in the performance of university mathematics teachers. With the use of technological resources or virtual platforms, an emotional distancing has been created. This distancing is reflected in university students. It is reflected in a higher number of failures and rejections towards the adoption of virtual mathematics. Retrotopia was evident in the comparison between the traditional and virtual model. Teachers emphasised that face-to-face classes were better and more 
effective. When running virtual classes, teachers were the least motivated.

Hence the need to consider emotionality in mathematics. This can be applied with digital didactics and better affective communication. These components develop motivating lessons to promote meaningful learning for students. In view of this, the importance of digital teaching of mathematics for the generation of knowledge is incalculable. University education requires an andragogic transformation and understanding. In this perspective, it is necessary to emphasise that it is required within the construction of scientific knowledge. The insertion of digital andragogical elements used in the teaching and learning process. Explicit elements within virtual reality, to lead to an integral formation of the mathematical being (Godino, 2010).

In terms of virtual assessment quality, it is one of the areas where there is a higher number of failures. Due to low performance, students who study teaching prefer social sciences, natural sciences, music, art or other areas, which have nothing to do with mathematical thinking. This is due to beliefs that they are afraid of mathematics education or other related sciences. These beliefs have been passed down from generation to generation. In this regard, Heefer (2019) points out that the traditional view of mathematics, where the student was punished to learn mathematical procedures, must be overcome. Today, the teacher must catalyse and provoke a motivating reaction to overcome the students' fear of mathematics. These actions should be mandatory for virtual teachers in times of the Covid-19 pandemic.

Similarly, teachers must undertake a humanistic teaching of mathematics. Actions aimed at developing mathematics immersed in everyday life must be integrated. In view of the above, it is necessary to highlight the transformation that mathematics has undergone in times of quarantine. Mathematics must move from a closed area to a flexible area that is specific to everyday life. In this way, the development of meaningful learning becomes a reality. All of this makes mathematics inescapable in the understanding of various elements.

After analysing the testimonies described by the informants, the interpretations issued in the research and the theoretical contexts through the qualitative analysis system. We conclude with the following theoretical approach: "There is a high deficit of teacher training for the teaching of virtual mathematics. The emotional logic of the Ecuadorian teacher leads him/her to portray a rigid academic being. A being that generates student fear and rejection in the educational community". 


\section{REFERENCES}

Alves P., Miranda L., Morais, C. \& Vieira, D. (2018). Learning styles of higher education students and access to virtual environment tools. Tendencias Pedagógicas, 31, 69-81.

Amalu, M. (2018). Emotional intelligence as predictor of academic performance among secondary school students in Makurdi Metropolis of Benue State. International Journal of Scientific Research in Education, 11(1), 63-70.

Arévalo, E., Guzmán, H. \& Sánchez, E. (2021). South Florida Journal of Development, 2(5), 6371-6381. 10.46932/sfjdv2n5-008.

Ausubel, D. (1976). Educational psychology. A cognitive point of view. Trillas.

Bauman, Z. (2017). Retrotopía. Polity Press.

Blumer, H. (1969). Symbolic Interactionism, Perspective and Method. University of California Press.

Bottia, M., Stearns, E., Mickelson, R., Moller, S. \& Jamil, C. (2020). The Importance of Community Colleges in Students' Choice to Major in STEM. The Journal of Higher Education, 91(7), 1116-1148. https://doi.org/10.1080/00221546.2020.1742032

Breda, A., Font, V. \& Pino, L. (2018), Valorative and normative criteria in the Didactics of Mathematics: the case of constructed didactic suitability. Bolema: Boletim de Educação Matemática, 32(60), 255-278. https://dx.doi.org/10.1590/1980-4415v32n60a13.

Cejas, M., Mendoza, D., Navarro, M., Rogel, L. \& Ortega, Y. (2019). A Performance-Centred Competency-Based Approach to Quality University Teaching. Integratsiya obrazovaniya, 23(3), 350365. https://doi.org/10.15507/1991-9468.096.023.201903.350-365

Díaz Barriga, F. (2002). Super Learning Strategies. Trillas.

Fatima, R. (2012). Role of Mathematics in the Development of Society. National Meet on Celebration of National Year of Mathematics. Organized by NCERT.

Fernández, C., Sánchez, G., Valls, J. \& Callejo, L. (2018). Noticing students mathematical thinking: characterization, development and contexts. Avances de Investigación en Educación Matemática, 13, 39 -61 .

Gadanidis, G., Clements, E. \& Yiu, Ch. (2018). Group Theory, Computational Thinking, and Young Mathematicians. Mathematical Thinking and Learning, 20(1), 32-53. https://doi.org/10.1080/10986065.2018.1403542

Gaitán, J. \& Lozano, C. (2012). Triangulation in the analysis of the social representation of climate change. Proceedings of the 2nd National Congress on Communication Research Methodology, 2, 559614.

García, P. (2011). Social Education. Editorial Siglo XXI. 
García, S., Miranda, Ch. \& García, C. (2019). Tick-based follow-up model of continuous teacher training. Runae, 2, $66-88$.

Godino, J. (2010). Teaching and learning mathematics. Edumat-Maestro.

Goleman, D. (1996). Emotional intelligence. Kairos.

Guerrero, R., Menezes, T. \& Ojeda, M. (2017). Scenario approximation in a phenomenological study in Mexico: experience report. Revista Brasileira de Enfermagem, 70(4), 885-90. https://doi.org/10.1590/0034-7167-2016-0601.

Guo, F., Hong, X. \& Coates, H. (2020). Accelerated transformation: designing global online higher education. Higher Education Research \& Development, 39(7), 1322-1326. https://doi.org/10.1080/07294360.2020.1824209

Heefer, A. (2019). Visual culture and mathematics in the early modern period. British Journal for the History of Mathematics, 34(3), 194-195. https://doi.org/10.1080/26375451.2019.1653066.

Iranzo, P., Camarero, M., Barrios, Ch., Tierno, J. \& Gilabert, S. (2018). What Do Teachers Think about School Leadership Competencies and Their Initial Training? Revista Iberoamericana sobre Calidad. Eficacia y Cambio en Educación, 16(3), 1-20. https://doi.org/10.15366/reice2018.16.3.002.

Katartzi, E. \& Hayward, G. (2020). Transitions to higher education: the case of students with vocational background. Studies in Higher Education, 45(12), 2371-2381. https://doi.org/10.1080 / 03075079.2019.1610866

Krishnapratap, S., Dasgupta, H. \& Vispute, S. (2020). Analysis of factors influencing international student destination choice: a case of Indian HE. Journal of Further and Higher Education, 44(10), 1388-1400. https://doi.org/10.1080/0309877X.2019.1690640

López, R. (2011). Social Manifestations of Human Thought. Paidos

Melgarejo, Ch. (2015). Teaching and Learning Mathematics. Universidad Autónoma de México.

Mendoza, D., Mendoza, D. \& Mendoza, E. (2018). Guidelines to Strengthen Positive Attitudes Towards Study at University Education. Mediterranean Journal of Social Sciences, 9(4), 19-29. https://doi.org/10.2478/mjss-2018-0111.

Mendoza, D., Nieto, Z. \& Vergel, M. (2019). Technology and mathematics as a cognitive component. Journal of Physics: Conference Series, 1414(012007). https://doi.org/10.1088/17426596/1414/1/012007.

Mendoza, D., Cejas, M., Navarro, M., Flores, E. \& Vega, V. (2020). Causes and Effects of the Division Algorithm Applied in Ecuadorian Education. International Journal of Instruction, 13(3), 61-74. https://doi.org/10.29333/iji.2020.1335a.

Mendoza, D., Cejas, M., Rivas, G. \& Varguillas, C. (2021). Anxiety as a prevailing factor of performance of university mathematics students during the COVID-19 pandemic. The Education and science journal, 23(2), 94-113. https://doi.org/10.17853/1994-5639-2021-2-94-113 
Mohd, N., Adibah, K., Nor, Z. \& Yudariah, M. (2016). The relationship between emotional intelligence and mathematical competency among secondary school students. Journal on Mathematics Education, 7(2), 91-100.

Ortiz, P., Giménez, A. y Rabal, J. (2021). Las matemáticas en educación primaria desde el prisma del estudiante de grado. South Florida Journal of Development, Miami, 2(4), 6278-6301. 10.46932/sfjdv2n4002.

Otzen, T. \& Manterola, C. (2017). Sampling techniques on a population to study. International Journal Morphology, 35(1), 227-232.

Pizarro, H. (2013). Cultural Manifestations of Education. Ediciones norma.

Rekalde, I., Vizcarra, M. \& Macazaga, A. (2014). Observation as a research strategy to build learning contexts and promote participatory processes. Educación XXI, 17(1), 199-220. https://doi.org/10.5944/educxx1.17.1.1074.

Salmerón, F. (2000). Emotionality. Editorial Trillas

Spindel, B. (2020). Better Positioned to Teach the Rules than to Change Them: University Actors in Two Low-Income, First-Generation Student Support Programs. The Journal of Higher Education, 91(3), 353377. https://doi.org/10.1080/00221546.2019.1647581.

Treffer, G. (2008). Componentes de la Enseñanza de la Matemática. Ediciones Siglo XXI.

Yerizon, A., Amadi, P. \& Muhammad, S. (2018). Mathematics Learning Instructional Development based on Discovery Learning for Students with Intrapersonal and Interpersonal Intelligence (Preliminary Research Stage). International electronic journal of mathematics education, 13(3), 97-10. https://doi.org/10.12973/iejme/2701

Young, E., Thompson, R., Sharp, J. \& Bosmans, D. (2020). Emotional transitions? Exploring the student experience of entering higher education in a widening-participation HE-in-FE setting. Journal of Further and Higher Education, 44(10), 1349-1363. https://doi.org/10.1080/0309877X.2019.1688264

Young, G. \& Suri, G. (2020). Emotion regulation choice: a broad examination of external factors. Cognition and Emotion, 34(2), 242-261. https://doi.org/10.1080/02699931.2019.1611544 